\title{
ANALISIS DATA MAGNETIK BAWAH PERMUKAAN UNTUK IDENTIFIKASI SEBARAN MINERAL MANGAN DESA TOLNAKU, KECAMATAN FATULEU, KABUPATEN KUPANG
}

\author{
Magnetic Data Analysis of Subsurface Mineral for Identifying \\ Manganese Mineral Distribution at Tolnaku Village, Fatuleu Sub \\ District, Kupang Regency
}

\author{
ASHARI J. AHMAD, MULFIN SYARIFIN, YOHANES A. DE SOUSA dan ISSER S. TUMALANG \\ Prodi Magister Teknik Pertambangan FTM - UPN “Veteran” Yogyakarta \\ Jalan SWK 104 (Lingkar Utara), Yogyakarta 55283 - Indonesia \\ e-mail: harahmad69@gmail.com
}

\begin{abstract}
ABSTRAK
Dengan metode base-rover, telah dilakukan penelitian magnetik bawah permukaan di wilayah blok satu IUP PT. Bhakti Alam Indonesia Timur menggunakan dua buah alat proton procession magnetometer (PPM) GSM 19 T. Data yang diperoleh berupa nilai medan magnet total sedangkan data variasi harian diperoleh dari Stasiun Geomagnetic Bumi Baumata, BMKG Kupang. Data tersebut dikoreksi menggunakan koreksi harian dan IGRF sehingga menghasilkan nilai anomali magnetik. Selanjutnya dilakukan interpretasi kualitatif dan kuantitatif anomali tersebut. Hasil interpretasi kualitatif diperoleh anomali magnetik pada kisaran -2056,50 925,51 nano Tesla. Nilai anomali magnetik yang terbesar adalah 925,51 nano Tesla. Anomali ini diduga mengandung batuan dengan densitas tinggi, rapat massa kompak, sangat keras dan berumur lebih tua dari batuan sekitar. Sedangkan nilai anomali magnetik terendah adalah $-2056,50$ nano Tesla. Anomali ini diduga mengandung batuan densitas rendah, rapat massa batuan sangat berongga, dan berumur paling muda dari batuan sekitar. Dari hasil interpretasi kuantitatif di Desa Tolnaku Kecamatan Fatuleu Kabupaten Kupang terdapat tiga jenis batuan yaitu lempung dengan suseptibilitas 0,0001 dan 0,0006 satuan cgs, sedimen dengan suseptibilitas 0,0031 satuan cgs, basalt dengan suseptibilitas 0,0121 dan 0,133 satuan cgs, dan mineral pirotit dengan suseptibilitas 0,0193 satuan cgs. Berdasarkan hasil interpretasi ini disimpulkan bahwa indikasi keberadaan lapisan batuan yang mengandung mangan di daerah penelitian semakin membesar ke arah selatan.
\end{abstract}

Kata kunci: metode geomagnet, suseptibilitas batuan, anomali, mangan.

\begin{abstract}
This research was conducted at IUP of PT. Bhakti Alam East Indonesia. The measurement method is a baserover using two 19T GSM proton magnetometer (PPM) devices. The obtained data are in the form of total magnetic field values while the daily variation data is obtained from the Baumata Earth Geomagnetic Station, BMKG Kupang. This data was correlated using both daily and IGRF correlations that results a magnetic anomaly value. Qualitative and quantitative interpretations of the anomaly were then carried out. The results show that the magnetic anomalies are in the range of -2056.50 - 925.51 nano Tesla. The largest magnetic anomaly is 925.51 nano Tesla. This anomaly is supposed to be rocks with high density, tight compact mass, very hard, and older than the surrounded rocks. While the lowest magnetic anomaly is -2056.50 nano Tesla. It refers to the rocks with low density, very hollow, and youngest in age compared to the surrounding rocks.
\end{abstract}


From quantitative interpretation results of Tolnaku Village, Fatuleu Subdistrict, Kupang Regency, there are three types of rocks, namely clay with susceptibility of 0.0001 and 0,0006 cgs units, sediment with 0.0031 cgs unit, basalt with 0.0121 and 0.133 cgs units, as well as pyrrhotite with 0.0193 cgs units. Based on the interpretation, it is concluded that the manganese containing rock in study area expand to the south.

Keywords: geomagnetic method, rock susceptibility, anomalies, manganese.

\section{PENDAHULUAN}

Mangan merupakan salah satu bahan galian yang paling banyak dieksplorasi di NTT khususnya di pulau Timor. Terbentuknya mineral mangan salah satunya akibat proses cebakan hidrotermal yang terbentuk dari larutan sisa magma (hidrotermal). Endapan hidrotermal juga masih mengandung konsentrasi logam yang terdapat dalam magma dan tidak ikut dalam proses pembekuan sebelumnya. Pada proses hidrotermal ini cairan magma akan mengisi celah-celah di dalam bumi seperti rekahanrekahan, pori-pori dan lubang-lubang kecil yang dilaluinya. Untuk mengetahui sebaran mineral tersebut diperlukan metode identifikasi sebaran bawah tanah.

Metode geomagnet adalah metode pengolahan data yang potensial untuk memperoleh gambaran bawah permukaan bumi berdasarkan karakteristik magnetiknya. Metode ini memanfaatkan sifat kemagnetan bumi sehingga diperoleh kontur yang menggambarkan distribusi suseptibilitas batuan bawah permukaan pada arah horizontal. Dari nilai ini dapat dipisahkan batuan yang mengandung sifat kemagnetan dengan yang tidak, sehingga dapat menentukan arah sebaran batuan itu sendiri (Rusita, Siregar dan Sota, 2016). Pada dasarnya penyelidikan geomagnet adalah mengukur besaran magnet bumi yang ditimbulkan oleh berbagai sumber, baik yang ada di dalam perut bumi maupun pengaruh dari luar, seperti radiasi matahari. (Telford, Geldart dan Sheriff, 1990).

Penelitian terdahulu oleh Hamsir (2015) telah menerapkan metode geomagnetik untuk memodelkan batuan penyusun bawah permukaan dan mengidentifikasikannya. Selanjutnya diteliti juga kemampuan batuan untuk menahan bangunan observatorium nasional yang akan didirikan di tempat tersebut. Hasil interpretasi kualitatif berdasarkan kondisi geologi dan pemodelan, diketahui bahwa masing-masing batuan tersebut adalah batugamping, batupasir, dan batuan metamorf jenis batusabak. Interpretasi kuantitatif menunjukan bahwa di lokasi tersebut nilai suseptibilitas batuan batusabak adalah 0,0018, 0,0019 dan 0,0033 cgs; batugamping $0,002,0,0003,0,0004$ dan 0,0008 cgs; dan batupasir 0,0001 cgs.

Tujuan penelitian ini adalah untuk mengetahui besarnya nilai anomali magnet, struktur bawah permukaan dan arah sebaran mineral mangan menggunakan metode geomagnet. Data ini kemudian dapat digunakan untuk penyelidikan lebih rinci dalam menentukan daerah yang memiliki prospek mineral mangan.

\section{GEOLOGI DAERAH PENELITIAN}

\section{Struktur Geologi Daerah Penelitian}

Lokasi penelitian berada pada wilayah ljin Usaha Pertambangan (IUP) PT. Bhakti Alam Indonesia Timur (Gambar 1). Kondisi Geologi di lokasi ini tidak lepas dari gejala geologi secara umum pulau Timor sehingga satuan atau formasi geologi yang terbentuk merupakan kesatuan kejadian geologi secara regional. Pulau Timor terletak pada Busur Banda Luar. Geologi dan struktur geologinya sangat rumit. Kerumitan geologi tercermin oleh beraneka ragamnya batuan berbagai umur yang bersentuhan secara struktur, yaitu batuan sedimen, beku, gunungapi dan malihan yang bersifat alokton maupun otokton (Rosidi dan Tjokrosapoetro, 1996). 


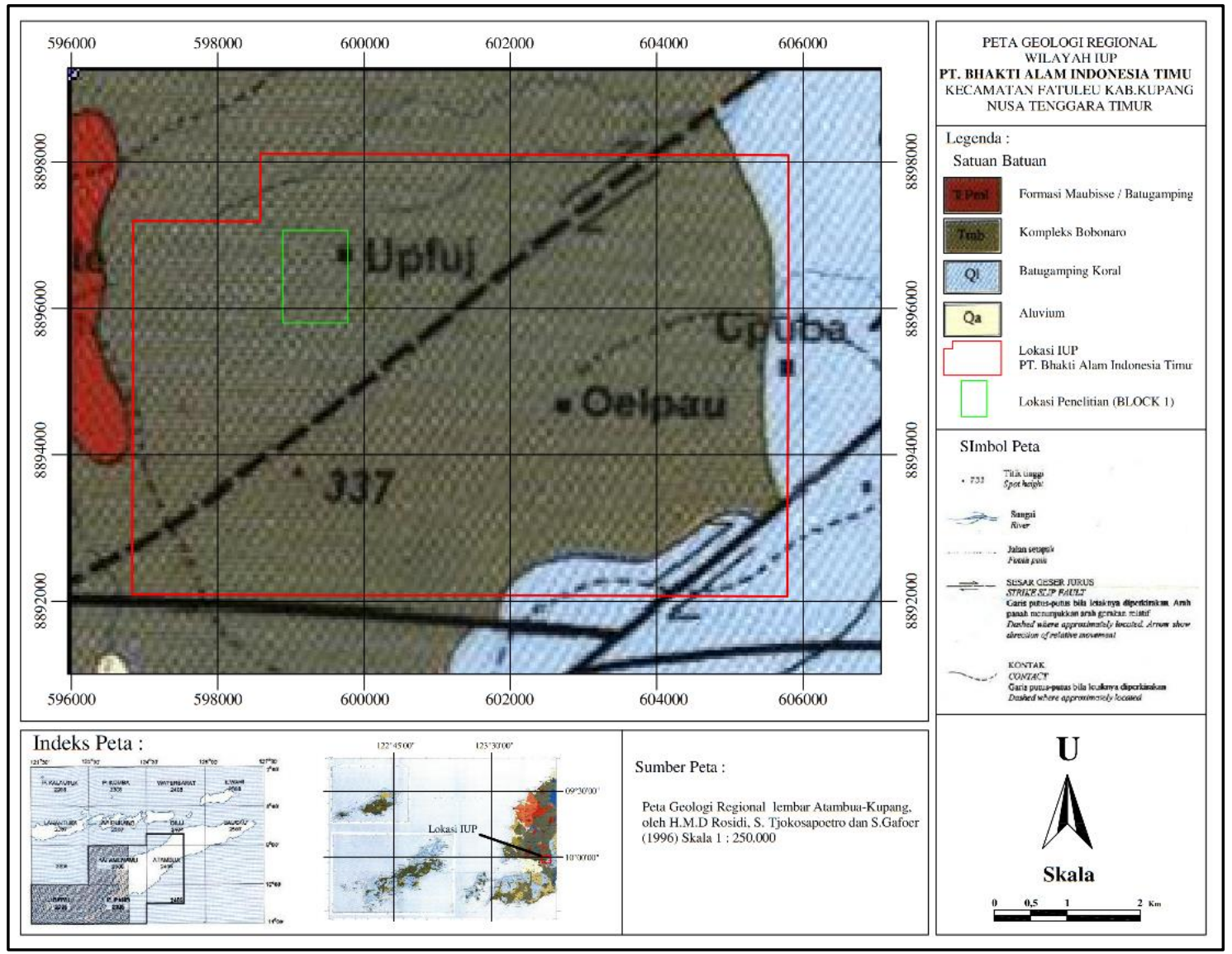

Sumber : PT. Bhakti Alam Indonesia Timur, 2015

Gambar 1. Peta geologi daerah penelitian

\section{METODE}

\section{Waktu dan Tempat Penelitian}

Pengambilan data geomagnet dilakukan dengan mengukur besar medan magnet total di titik-titik yang telah ditentukan pada kawasan penelitian dan dilaksanakan pada 1 sampai 5 Desember 2015. Lokasi penelitian terletak di Desa Tolnaku Kecamatan Fatuleu Kabupaten Kupang.

\section{Prosedur Pelaksanaan Penelitian}

Tahapan pengambilan data meliputi :

1. Membuat desain survei berdasarkan lokasi yang telah direncanakan. Pembuatan desain ini dilakukan secara kisi-kisi untuk 256 titik pengamatan, dengan jarak antar lintasan $\pm 100 \mathrm{~m}$ dan antar titik $\pm 30 \mathrm{~m}$.
2. Mempersiapkan semua alat yang akan digunakan serta mengkalibrasi global positioning system (GPS) dan proton procession magnetometer (PPM).

3. Survei lapangan untuk menemukan lokasi koordinat titik pengukuran yang telah di desain. Tahap ini juga dilakukan untuk mencari lokasi pengukuran yang tidak dekat dengan benda-benda yang memiliki nilai kemagnetan tinggi seperti logam, pagar kawat, jaringan listrik, untuk mengurangi noise (Gambar 2).

4. Apabila titik pengukuran telah diperoleh, dilakukan pembersihan lahan bila pada titik pengambilan data tersebut terdapat semak belukar dan selanjutnya dilakukan penandaan (marking) ulang.

5. Melakukan pencatatan hasil dan waktu pengukuran. Pada satu titik pengukuran dilakukan tiga kali pembacaan medan magnet. 


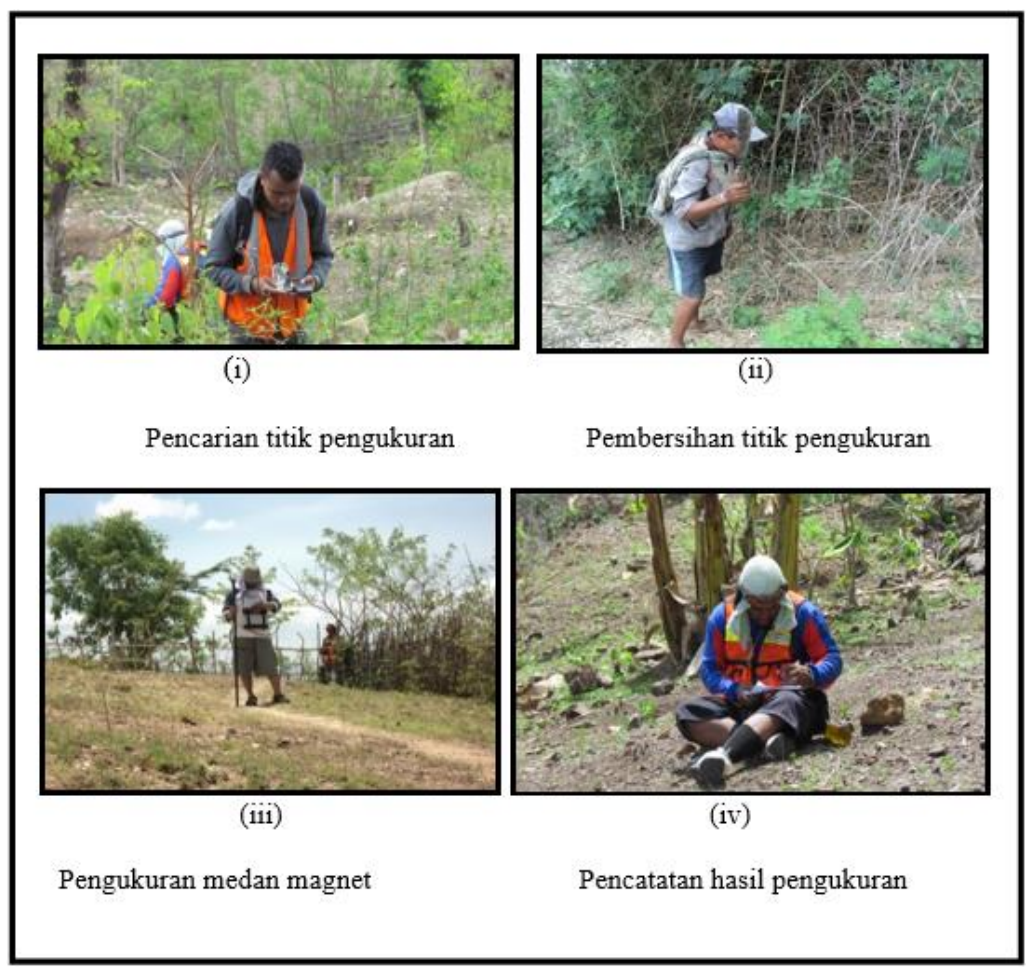

Sumber: Data olahan penulis, 2016

Gambar 2. Rangkaian kegiatan pengukuran medan magnet

\section{Analisis Data}

Medan magnet hasil pengukuran di lapangan dipengaruhi oleh medan magnet luar, medan magnet utama, dan anomali medan magnet itu sendiri. Untuk mendapatkan besarnya anomali medan magnet di lapangan, medan magnet luar dan medan magnet utama perlu dihilangkan. Medan magnet luar dihilangkan dengan koreksi variasi harian, dan medan magnet utama dihilangkan dengan koreksi IGRF (Firmansyah dan Budiman, 2019). Nilai IGRF dapat diperoleh dari situs National Geophysical Data Centre (NGDC) secara online. Nilai IGRF yang diperoleh untuk daerah penelitian yaitu 45212,1 nano Tesla.

Untuk menghitung nilai anomali magnetik dari data medan total di lokasi penelitian dilakukan dengan persamaan:

$\mathrm{HA}=\mathrm{H}_{\text {total }}-\mathrm{H}_{\mathrm{GGRF}} \pm \Delta \mathrm{H}_{\text {harian }}$

Keterangan :

$\mathrm{HA} \quad=$ Anomali Magnetik

$\Delta \mathrm{H}_{\text {harian }}=$ Variasi Harian

$\mathrm{H}_{\text {total }}=$ Medan magnet total

HIGRF = Nilai IGRF
Pengukuran yang dilakukan menggunakan metode base-rover yang dianggap paling akurat karena mencatat nilai variasi harian setiap 12 detik (Takaeb, Sutaji dan Bernandus, 2018). Metode ini menggunakan dua buah alat proton procession magnetometer (PPM). Satu buah alat digunakan untuk pengambilan database yang ditempatkan pada tempat yang bebas dari noise untuk mencatat nilai variasi harian, sedangkan yang lainnya mencatat intensitas medan total tiap lintasan.

\section{HASIL DAN PEMBAHASAN}

\section{Koreksi}

1. Koreksi Harian

Koreksi harian dilakukan untuk menghilangkan penyimpangan nilai medan magnetik bumi akibat adanya perbedaan waktu dan gangguan radiasi matahari yang menghasilkan ionisasi lapisan atmosfir bagian atas. Adanya ionisasi dan elektron-elektron yang terlempar dari matahari akan menimbulkan arus sebagai sumber medan magnetik (Panjaitan, 2015). 
Apabila nilai variasi harian negatif, koreksi harian dilakukan dengan cara menambahkan nilai variasi harian yang terekam pada waktu tertentu terhadap data medan magnetik yang akan dikoreksi. Sebaliknya apabila variasi harian bernilai positif, koreksinya dilakukan dengan cara mengurangkan nilai variasi harian yang terekam pada waktu tertentu terhadap data medan magnetik yang akan dikoreksi (Utama dkk., 2016). Secara matematis dapat dituliskan dalam persamaan

$\Delta \mathrm{H}=\mathrm{H}_{\text {total }} \pm \Delta \mathrm{H}_{\text {harian }}$

Keterangan :

$\Delta \mathrm{H} \quad=$ Koreksi harian

$\mathrm{H}_{\text {total }}=$ Medan total bumi

$\Delta \mathrm{H}_{\text {harian }}=$ Variasi harian.

2. Koreksi International Geomagnetik Reference Field (IGRF)

Medan magnet utama bumi berubah terhadap waktu. Untuk menyeragamkan nilai-nilai medan utama magnet bumi, dibuat standar nilai yang disebut international geomagnetics reference field (IGRF) yang diperbaharui setiap 5 tahun sekali (Telford, 1976 dalam Heningtyas, Wibowo dan Darmawan, 2017). Koreksi IGRF digunakan untuk menghilangkan nilai medan magnet bumi yang tergabung dengan data anomali magnetik saat pengambilan data di tempat penelitian.

\section{Interpretasi}

1. Interpretasi Kualitatif

Interpretasi kualitatif didasarkan pada pola kontur anomali medan magnetik yang bersumber dari distribusi benda-benda termagnetisasi atau struktur geologi bawah permukaan bumi. Selanjutnya pola anomali medan magnetik yang dihasilkan ditafsirkan berdasarkan informasi geologi setempat dalam bentuk distribusi benda magnetik atau struktur geologi, yang dijadikan dasar pendugaan terhadap keadaan geologi yang sebenarnya (Awaliyatun dan Hutahean, 2015).

Setelah dilakukan koreksi pada data medan magnetik, akan diperoleh data anomali magnetik yang selanjutnya diolah dengan bantuan perangkat lunak (software) Surfer dan menghasilkan peta anomali magnetik pada Gambar 3. Dari Gambar 3 tampak bahwa anomali magnetik di lokasi penelitian berada pada kisaran nilai 2056,5 sampai 925,51 nano Tesla. Dalam hal ini anomali magnetik dapat dikelompokan menjadi 2, yaitu anomali magnetik yang bernilai positif dan bernilai negatif. Anomali positif dengan rentang nilai antara 0 sampai 925,51 nano Tesla dan anomali negatif dengan rentang nilai antara -2056,5 sampai $<0$ nano Tesla.

Anomali magnetik dengan nilai positif dan tinggi diduga mengandung batuan dengan densitas tinggi, rapat massa kompak, sangat keras dan berumur lebih tua dari batuan sekitar diduga merupakan batuan basalt. Sedangkan anomali magnetik dengan nilai anomali bernilai negatif diduga mengandung batuan dengan densitas rendah, rapat massa batuan sangat berongga, dan berumur muda diduga sebagai lempung (Tahaob, 2014).

2. Interpretasi Kuantitatif

Interpretasi kuantitatif dilakukan untuk menggambarkan struktur bawah permukaan dari data yang terukur di lapangan dengan pemodelan matematis dua dimensi (2D) menggunakan software Mag2Dc (Fitria, Yulianto dan Harmoko, 2015). Dengan membuat model, struktur bawah permukaan dapat diketahui berdasarkan nilai suseptibilitas setiap batuan dan mineral yang tersebar di lokasi penelitian.

Dari peta anomali magnetik pada Gambar 3, dibuat penampang untuk mendapatkan data dalam pembuatan model dua dimensi (2D), dari data hasil penampang pada peta anomali magnetik tersebut mewakili anomali magnetik di bawah permukaan. Dalam penelitian ini, peneliti membuat model dengan 3 penampang. Koordinat dari 3 penampang tersebut ditunjukan pada Tabel 1. 


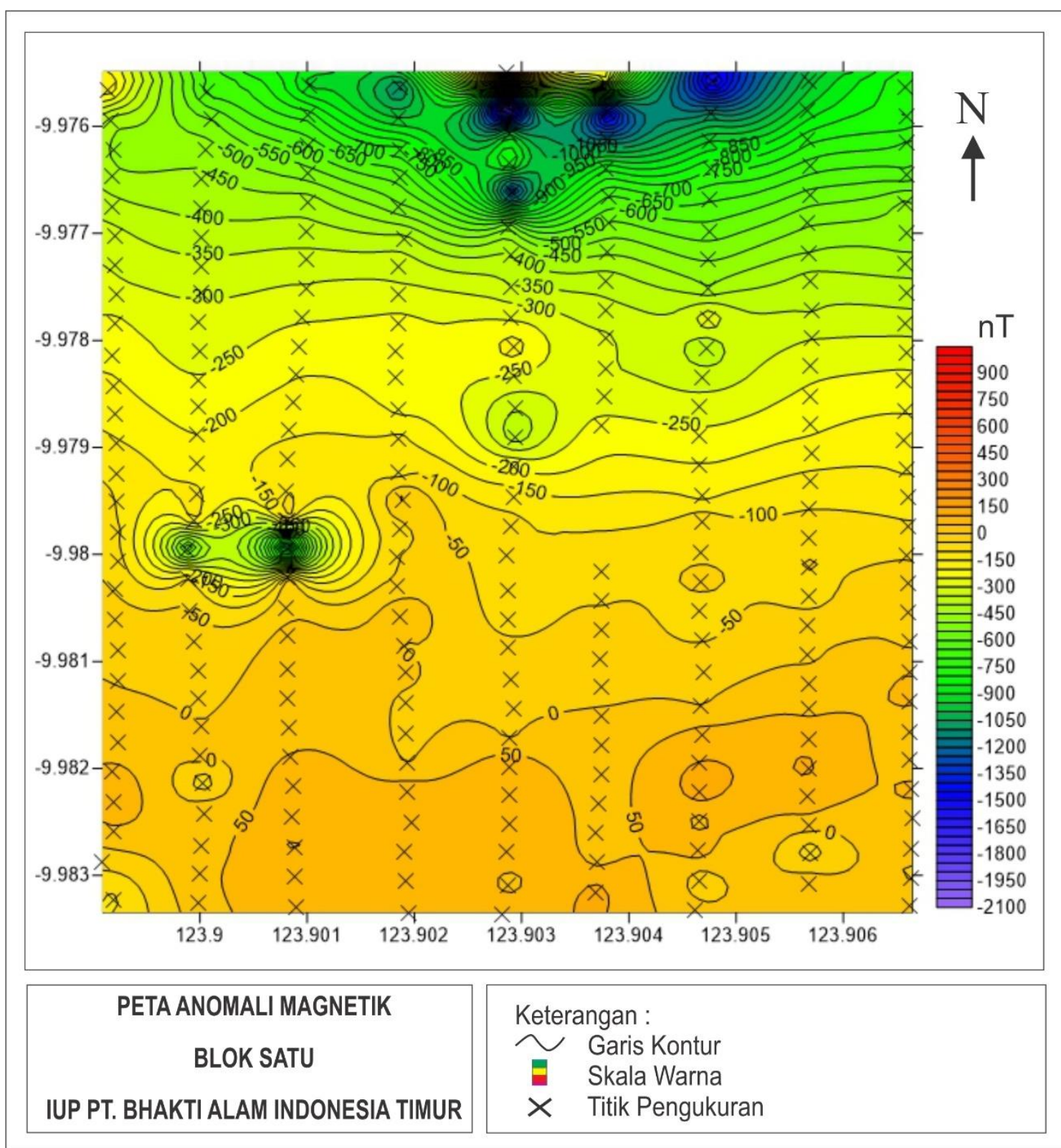

Sumber : Data olahan penulis, 2016

Gambar 3. Peta anomali magnetik (interval 50 nano Tesla)

Tabel 1. Koordinat penampang

\begin{tabular}{cll}
\hline Penampang & Bujur Timur & Lintang Selatan \\
\hline A & 123.8996 & -9.98202 \\
A $^{\prime \prime}$ & 123.9062 & -9.98288 \\
B & 123.9032 & -9.98192 \\
B" $^{\prime \prime}$ & 123.9064 & -9.97775 \\
C & 123.8996 & -9.97960 \\
C" $^{\prime \prime}$ & 123.9023 & -9.97680 \\
\hline
\end{tabular}

Penampang-penampang yang dibuat pada Gambar 4 diusahakan untuk memotong kontur anomali magnetik yang berbedabeda, sehingga dapat diketahui batuan yang ada pada kontur anomali magnetik tersebut dan mempermudah dalam menentukan model batuannya.

Pembuatan model dengan program Mag2Dc dilakukan menggunakan metode trial and error. Metode tersebut mengharuskan peneliti untuk melakukan uji coba selama memodelkan struktur perlapisan batuan (Setiadi, Darmawan dan Marjiyono, 2016). 


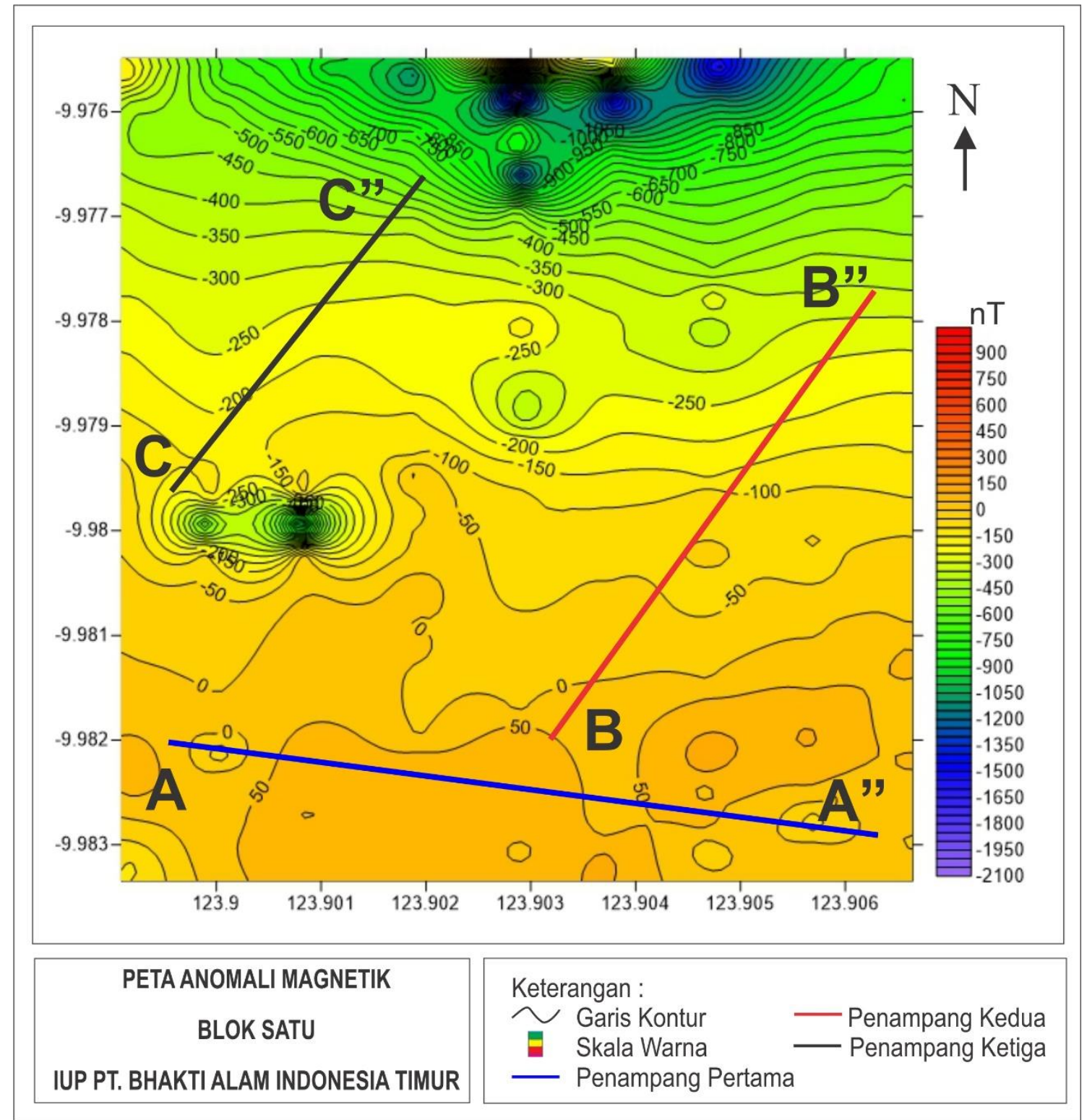

Sumber : Data olahan Penulis, 2016

Gambar 4. Sayatan pada peta anomali magnetik

Untuk membuat model pada program Mag2Dc diperlukan input data yang diperoleh dari situs National Geophysical Data Centre (NGDC) berupa nilai sudut inklinasi sebesar -35,5506 derajat, sudut deklinasi sebesar 1,7079 derajat, kedalaman maksimum yang ditampilkan 50 meter, nilai suseptibilitas batuan atau mineral yang sesuai keadaan geologi lokasi penelitian serta nilai IGRF.

Parameter yang diubah-ubah untuk mendapatkan gambaran struktur perlapisan batuan adalah bentuk model, kedalaman dan nilai suseptibilitas.

Pengubahan parameter tersebut dilakukan secara terus menerus hingga nilai anomali uji coba mendekati nilai anomali hasil pengukuran di lokasi penelitian (metode trial and error). Hal ini ditandai dengan semakin berimpitnya grafik anomali uji coba (garis utuh) dengan grafik anomali hasil pengukuran di lokasi penelitian (Deniyanto, 2010). 
Tabel 2. Daftar suseptibilitas batuan dan mineral

\begin{tabular}{|c|c|c|}
\hline \multirow{2}{*}{$\begin{array}{c}\text { Jenis Batuan / } \\
\text { Mineral }\end{array}$} & \multicolumn{2}{|c|}{ Suseptibilitas (x 10-6 emu) } \\
\hline & Interval & Rata-rata \\
\hline \multicolumn{3}{|l|}{ Batuan Sedimen } \\
\hline Dolomit & $0-75$ & 10 \\
\hline Batugamping & $2-280$ & 25 \\
\hline Batupasir & $0-1660$ & 30 \\
\hline Lempung & $5-1480$ & 50 \\
\hline Av. Sedimentary & $0-4000$ & 75 \\
\hline \multicolumn{3}{|l|}{ Batuan Metamorf } \\
\hline Amfibolit & & 60 \\
\hline Sekis (schist) & $25-240$ & 120 \\
\hline Fillite & & 130 \\
\hline Genes & $10-2000$ & \\
\hline Kuarsit & & 350 \\
\hline Serpentin & $250-1400$ & \\
\hline Batusabak & $0-3000$ & 500 \\
\hline Av. Metamorphic & $0-5800$ & \\
\hline \multicolumn{3}{|l|}{ Batuan Beku } \\
\hline Granit & $0-4000$ & 200 \\
\hline Riolit & $20-3000$ & \\
\hline Dolorit & $100-3000$ & 1400 \\
\hline Augit-senit & $2700-3600$ & \\
\hline Olivin-diabas & & 2000 \\
\hline Diabas & $80-13000$ & 4500 \\
\hline Porfiri & $20-16700$ & 5000 \\
\hline Gabro & $80-7200$ & 6000 \\
\hline Basal & $20-14500$ & 6000 \\
\hline Diorit & $50-10000$ & 7000 \\
\hline Piroksenit & & 10500 \\
\hline Peridotit & $7600-15600$ & 13000 \\
\hline Andesit & & 13500 \\
\hline Av. Acid Igneous & $3-6530$ & 650 \\
\hline Av. Basic lgneous & $44-9710$ & 2600 \\
\hline \multicolumn{3}{|l|}{ Mineral } \\
\hline Grafit & & -8 \\
\hline Kuarsa & & -1 \\
\hline $\begin{array}{l}\text { Anhidrit, } \\
\text { batugamping }\end{array}$ & & -1 \\
\hline Kalsit & $-0.6--1$ & \\
\hline Batubara & & 2 \\
\hline Tanah liat & & 20 \\
\hline Kalkopirit & & 32 \\
\hline Sfalerit & & 60 \\
\hline Kasiterit & & 90 \\
\hline Siderit & $100-310$ & \\
\hline Pirit & $4-420$ & 130 \\
\hline Limonit & & 220 \\
\hline Garam batu & & -1 \\
\hline Arsenopirit & & 240 \\
\hline Hematit & $40-3000$ & 550 \\
\hline Kromit & $240-9400$ & 600 \\
\hline Franklinit & & 36000 \\
\hline Pirotit & $100-500000$ & 125000 \\
\hline Ilmenit & $25000-300000$ & 150000 \\
\hline Magnetit & $100000-1600000$ & 500000 \\
\hline
\end{tabular}

Sumber : Telford dkk., 1990
Jika kedua grafik telah saling berimpit, dapat disimpulkan bahwa model perlapisan batuan bawah permukaan penampang sudah mendekati kondisi sebenarnya, sehingga nilai suseptibilitas setiap poligon diambil untuk menginterpretasi jenis-jenis batuan hasil pemodelan dengan cara membandingkan antara nilai suseptibilitas setiap poligon dengan standar tabel suseptibilitas batuan.

Nilai suseptibilitas hasil pemodelan dalam bentuk satuan CGS sehingga harus dikonversi ke satuan SI yaitu dikali $10^{6}$. Nilai suseptibilitas hasil konversi disesuaikan dengan nilai standar suseptibilitas batuan untuk diinterperetasi jenis batuan tersebut.

\section{- Penampang Lintasan A-A"}

Hasil permodelan penampang A-A" dengan panjang 725,7 m, menghasilkan 2 model bongkahan yang memiliki suseptibilitas berbeda (Gambar 5). Bongkahan pertama berwarna hijau dengan nilai suseptibilitas 0,0001 cgs dan diperkirakan sebagai jenis lempung dengan ketebalan $\pm 36 \mathrm{~m}$. Bongkahan kedua berwarna abu-abu dengan nilai suseptibilitasnya 0,0031 cgs dan diperkirakan sebagai av. sedimentary dengan ketebalan $\pm 32 \mathrm{~m}$.

Pada penampang lintasan ini terlihat di bagian bawah adanya kenaikan nilai suseptibilitas. Hal ini disebabkan oleh adanya bidang kontak batuan antara bongkahan 1 dengan 2. Selisih nilai suseptibilitas antara bongkahan tersebut sebesar 0,003 satuan cgs.

- Penampang Lintasan B-B"

Hasil permodelan penampang B-B" dengan panjang $673,5 \mathrm{~m}$, menghasilkan 3 model bongkahan yang memiliki suseptibilitas yang berbeda (Gambar 6). Bongkahan pertama berwarna hijau dengan nilai suseptibilitas 0,0001 cgs, diperkirakan sebagai lempung dengan ketebalan \pm 34 $\mathrm{m}$. Bongkahan kedua berwarna merah dengan nilai suseptibilitas-nya 0,0121 cgs, diperkirakan sebagai basalt dengan ketebalan $\pm 22 \mathrm{~m}$. Bongkahan ketiga berwarna hijau dengan nilai suseptibilitasnya 0,0006 cgs, diperkirakan sebagai lempung dengan ketebalan $\pm 40 \mathrm{~m}$. 


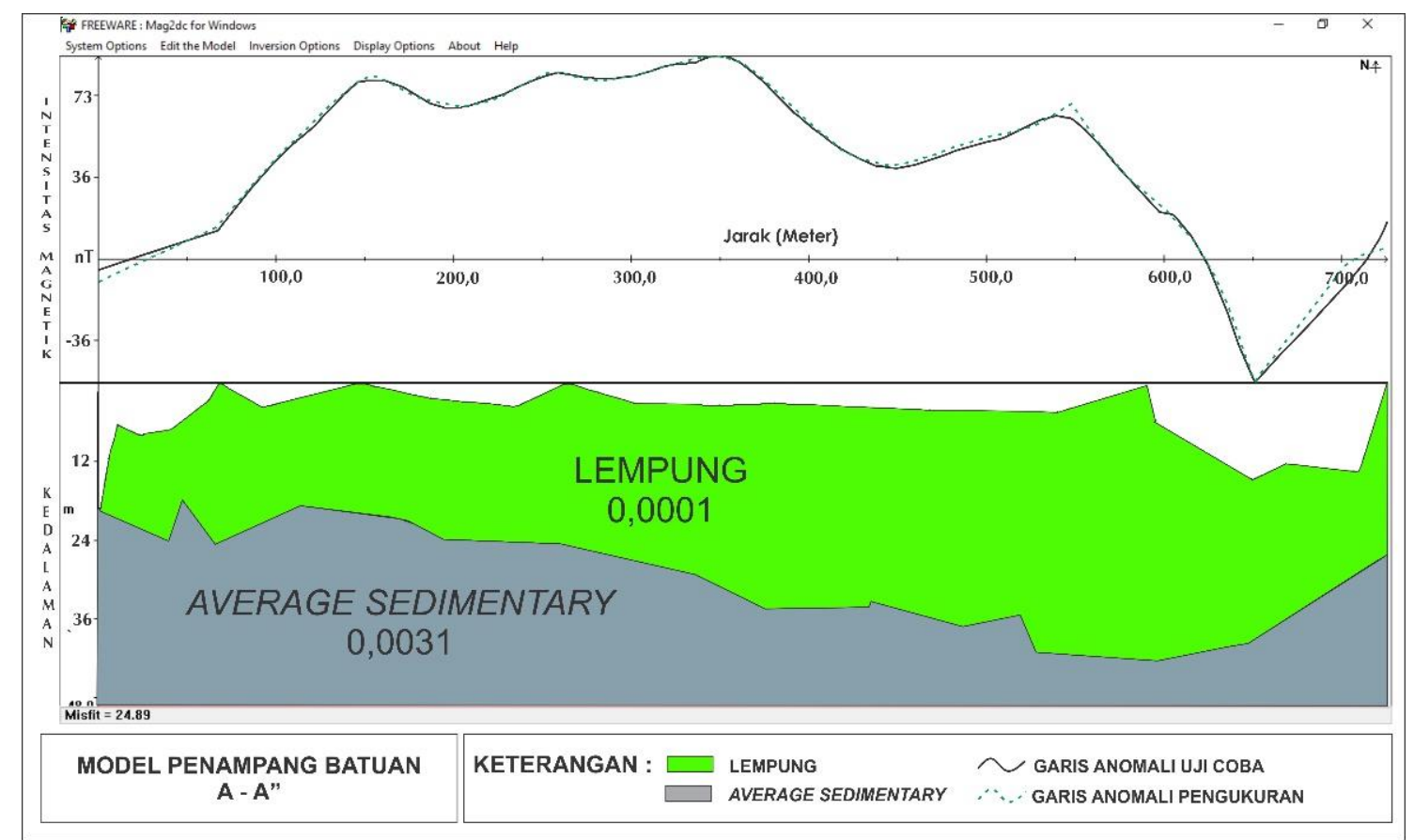

Sumber : Data olahan penulis, 2016

Gambar 5. Model penampang batuan A-A"

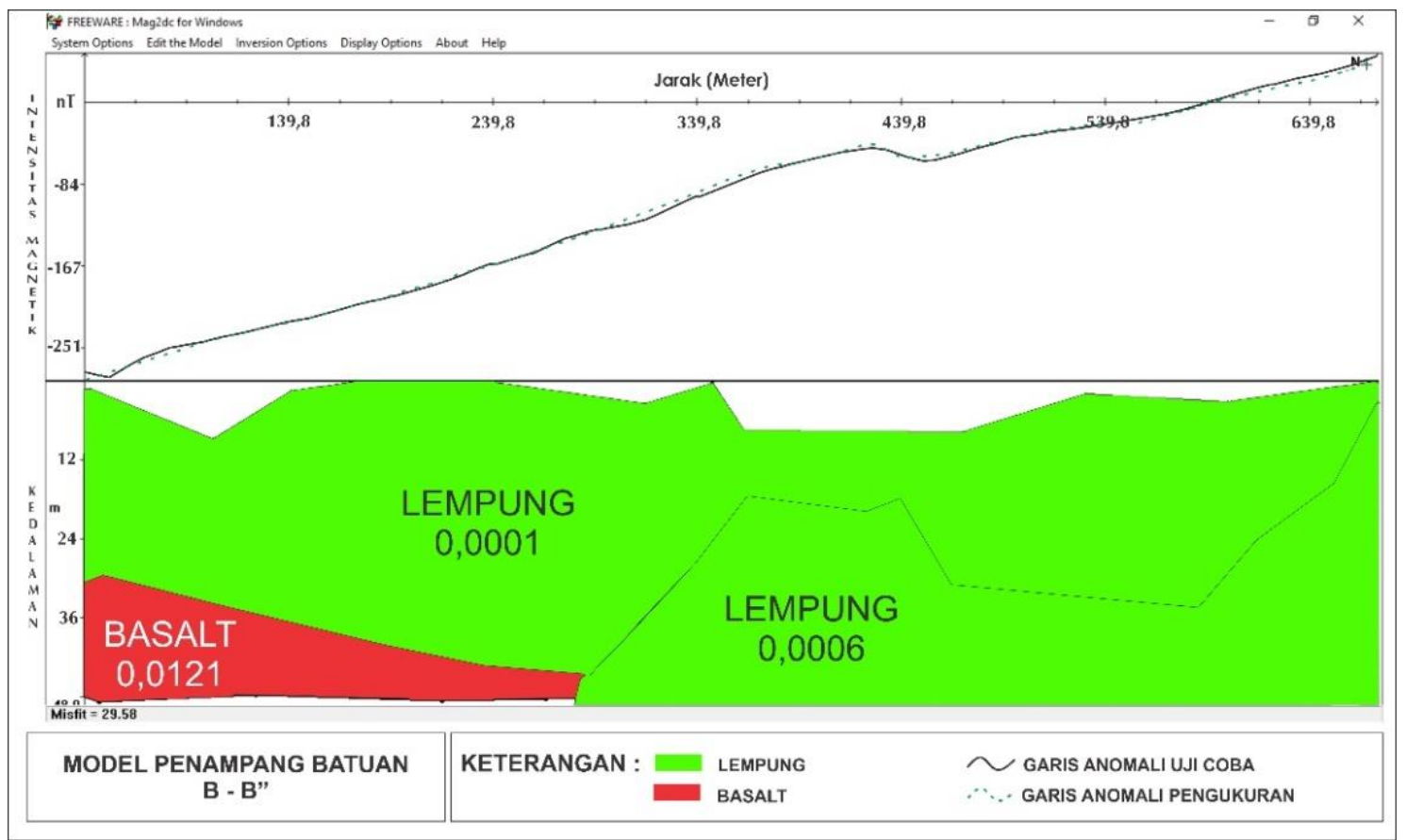

Sumber : Data olahan penulis, 2016

Gambar 6. Model penampang batuan B-B"

Pada penampang lintasan ini di bagian selatan terlihat adanya perubahan nilai suseptibilitas antara bongkahan atas dan bawah. Hal ini disebabkan oleh adanya bidang kontak batuan antara bongkahan 1 dengan 2. Selisih nilai suseptibilitas antara bongkahan 1 dan 2 tersebut sebesar 0,012 cgs. Pada bagian tengah sampai ke timur 
lintasan terjadi peningkatan nilai anomali magnetik. Perubahan tersebut disebabkan adanya rekahan (retakan) yang terjadi pada batuan tersebut. Hal ini terlihat dari nilai suseptibilitas batuan pada bongkahan 1 yang tidak jauh berbeda dengan bongkahan 3. Selisih nilai suseptibilitas bongkahan 1 dan 3 tersebut adalah 0,0005 cgs.

\section{- Penampang Lintasan C-C"}

Hasil permodelan penampang C-C" dengan panjang 531,8 meter, menghasilkan 3 model bongkahan yang memiliki suseptibilitas berbeda (Gambar 7). Bongkahan pertama berwarna hijau dengan nilai suseptibilitas 0,0001 cgs dan diperkirakan sebagai lempung dengan ketebalan \pm 30 m. Bongkahan kedua berwarna merah dengan nilai suseptibilitasnya 0,0133 cgs dan diperkirakan sebagai basalt dengan ketebalan $\pm 26 \mathrm{~m}$. Bongkahan ketiga berwarna kuning perunggu dengan nilai suseptibilitasnya 0,0193 cgs dan diperkirakan sebagai mineral pirotit dengan ketebalan \pm 28 meter.

Pada penampang lintasan ini terlihat di bagian barat adanya perubahan nilai suseptibilitas antara bongkahan atas dan bawah. Hal ini disebabkan oleh adanya bidang kontak batuan antara bongkahan 1 dengan bongkahan 2. Selisih nilai suseptibilitas antara bongkahan 1 dan 2 tersebut sebesar 0,0132 satuan cgs. Pada bagian tengah sampai ke utara lintasan terjadi peningkatan nilai anomali magnetik. Perubahan tersebut disebabkan oleh adanya rekahan (retakan) yang terjadi pada batuan. Hal tersebut terlihat dari nilai suseptibilitas batuan pada bongkahan 2 yang tidak jauh berbeda dengan bongkahan 3. Selisih nilai suseptibilitas bongkahan 2 dan 3 tersebut adalah 0,006 satuan cgs.

Hasil interpretasi dari ketiga pemodelan sayatan penampang bawah permukaan yang ada, diinterpretasikan bahwa batuan di bawah permukaan didominasi oleh lempung, rata-rata sedimen, batuan basalt serta mineral pirotit. Hasil pemodelan juga menunjukkan kesesuaian dengan hasil interpretasi kondisi geologi daerah penelitian, yang terdiri atas satuan batuan lempung bersisik dengan batuan penyusunnya batu lempung.

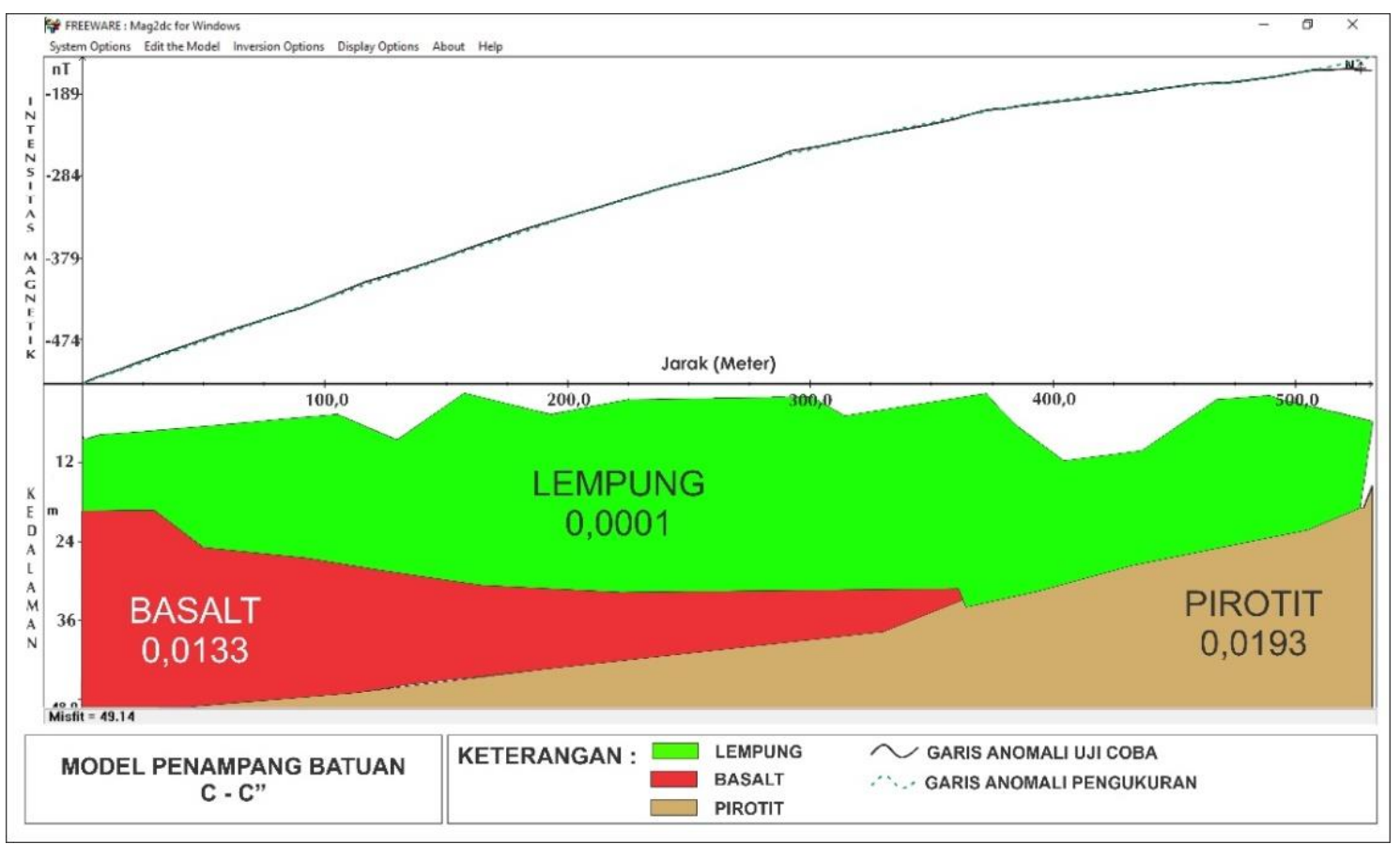

Sumber : Data olahan penulis, 2016

Gambar 7. Model penampang batuan C-C" 


\section{Kalibrasi}

Pengertian kalibrasi di sini adalah membandingkan pengukuran medan magnet di dekat singkapan mangan bekas tambang rakyat dengan hasil pemodelan geomagnet. Cara ini diperlukan karena di daerah penelitian tidak ada data pemboran.
Melalui kalibrasi ini dapat ditentukan kisaran nilai anomali magnetik untuk lapisan batuan yang mengandung $\mathrm{Mn}$ sehingga dapat ditentukan penyebarannya. Kalibrasi dilakukan di titik pengukuran yang dekat dengan bekas tambang rakyat. Foto udara peta lokasi kalibrasi dapat dilihat pada Gambar 8.

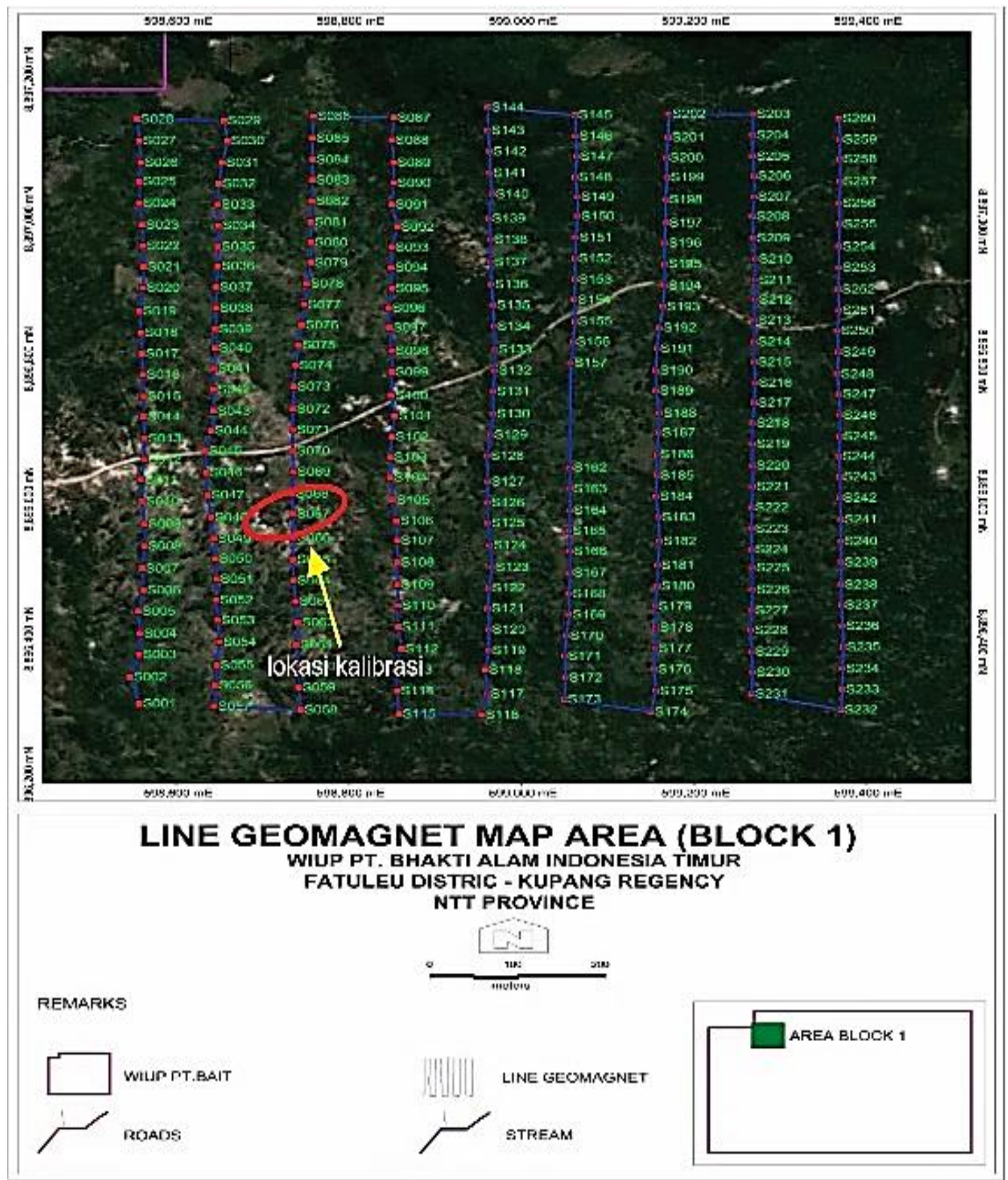

Sumber : PT. Bhakti Alam Indonesia Timur, 2015

Gambar 8. Foto udara lokasi pengkuran untuk kalibrasi (tanda panah) 
Hasil pengukuran pada titik yang berada di atas singkapan lapisan batuan yang mengandung mangan menghasilkan anomali magnetik bernilai positif ditandai dengan warna oranye di peta anomali magnetik (Gambar 3). Dari pengukuran tersebut disimpulkan bahwa indikasi keberadaan lapisan batuan yang mengandung mangan tersebar di bagian selatan wilayah pengukuran medan magnetik.

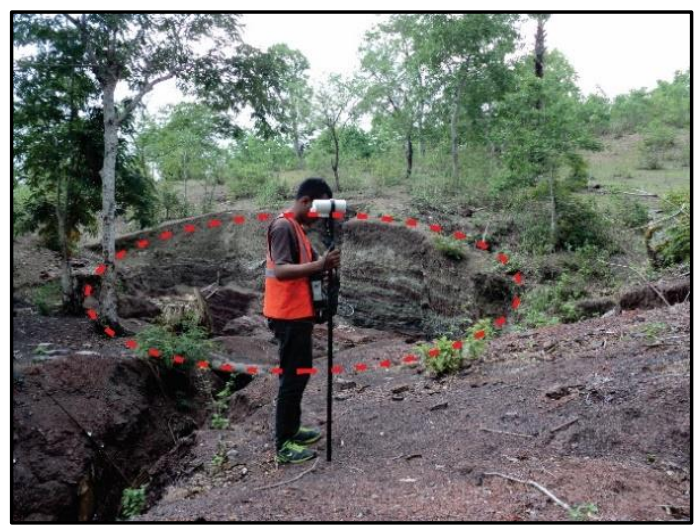

Sumber: PT. Bhakti Alam Indonesia Timur, 2016

Gambar 9. Pengukuran medan magnet dekat bekas tambang rakyat

\section{KESIMPULAN DAN SARAN}

\section{Kesimpulan}

Berdasarkan hasil pemetaan anomali magnetik diduga mineral mangan berasosiasi dengan lempung dan anomali magnetiknya sebesar 0,0001 cgs pada penampang A-A". Diperkirakan zona mineralisasi mangan terletak pada kedalaman 5 sampai dengan 35 $\mathrm{m}$ di bawah permukaan tanah

\section{Saran}

1. Perlu dilakukan verifikasi dengan sumur uji, paritan dan pengeboran di area blok satu PT. Bhakti Alam Indonesia Timur untuk membuktikan hasil interpretasi, karena metode geomagnet hanya merupakan metode pendugaan.

2. Perlu dilakukan sosialisasi kepada masyarakat secara menyeluruh dan berkelanjutan untuk mendukung kegiatan eksplorasi di lokasi Wilayah IUP PT. Bhakti Alam Indonesia Timur.

\section{UCAPAN TERIMA KASIH}

Penulis mengucapkan terimakasih kepada Universitas Nusa Cendana dan PT. Bhakti Alam Indonesia Timur yang telah memberikan kesempatan kepada penulis untuk melakukan penelitian dan pengambilan data di lokasi kegiatan eksplorasi pertambangan, sehingga penulis dapat menyelesaikan penelitian.

\section{DAFTAR PUSTAKA}

Awaliyatun, F. Z. dan Hutahean, J. (2015) "Penentuan struktur bawah permukaan tanah daerah potensi panas bumi dengan metode geomagnetik di Tinggi Raja Kabupaten Simalungun," Jurnal Einstein, 3(1), hal. 1-7.

Deniyanto (2010) Pemodelan ke depan (forward modelling) 2 dimensi data magnetik untuk identifikasi bijih besi di lokasi $X$, Provinsi Sumatera Barat. Universitas Halouleo.

Firmansyah, F. dan Budiman, A. (2019) "Pendugaan mineralisasi emas menggunakan metode magnetik di Nagari Lubuk Gadang Kecamatan Sangir, Solok Selatan, Sumatera Barat," Jurnal Fisika Unand, 8(1), hal. 77-83.

Fitria, L., Yulianto, T. dan Harmoko, U. (2015) "Interpretasi struktur bawah permukaan berdasarkan data geomagnetik pada daerah mata air panas Jatikurung Kabupaten Semarang," Youngster Physics Journal, 4(4), hal. 285-290.

Hamsir, H. (2015) Pemodelan dua dimensi metode geomagnet pada lokasi rencana pembangunan observatorium nasional wilayah Timau Kecamatan Amfoang Tengah Kabupaten Kupang. Universitas Nusa Cendana.

Heningtyas, Wibowo, N. B. dan Darmawan, D. (2017) "Interpretasi struktur bawah permukaan dengan metode geomagnet di jalur Sesar Oyo," Jurnal Fisika, 6(2), hal. 138148.

Panjaitan, M. (2015) “Penerapan metode magnetik dalam menentukan jenis batuan dan mineral," Jurnal Riset Komputer (JURIKOM), 2(6), hal. 69-72.

Rosidi, H. M. D. dan Tjokrosapoetro, S. (1996) Peta geologi lembar Kupang - Atambua, Timor: Geological map of Kupang - Atambua quadrangles, Timor. Bandung: Pusat Penelitian dan Pengembangan Geologi. 
Rusita, S., Siregar, S. S. dan Sota, I. (2016) "Identifikasi sebaran bijih besi dengan metode geomagnet di daerah Pemalongan, Bajuin Tanah Laut," Jurnal Fisika FLUX, 13(1), hal. 49-59.

Setiadi, I., Darmawan, A. dan Marjiyono (2016) "Pendugaan struktur geologi bawah permukaan daerah terdampak lumpur Sidoarjo (Lusi) berdasarkan analisis data geomagnet," Jurnal Lingkungan dan Bencana Ceologi, 7(3), hal. 125-134.

Tahaob, P. (2014) Identifikasi anomali magnetik bawah permukaan menggunakan metode geomagnet di area penambangan batuan gamping pada PT Sarana Agra Gemilang KSO PT Semen Kupang di Kecamatan Alak Kota Kupang. Universitas Nusa Cendana.
Takaeb, Y., Sutaji, H. I. dan Bernandus, B. (2018) "Interpretasi jenis batuan menggunakan metode geomagnetik pada daerah terakumulasinya air tanah di bena amanuban selatan," Jurnal Fisika: Fisika Sains dan Aplikasinya, 3(2), hal. 126-131. doi: 10.35508/fisa.v3i2.613.

Telford, W. M., Geldart, L. P. dan Sheriff, R. E. (1990) Applied geophysics. Cambridge: Cambridge University Press (Monograph series). doi: 10.1017/CBO9781139167932.

Utama, W., Warnana, D. D., Hilyah, A., Bahri, S., Syaifuddin, F. dan Rismayanti, H. F. (2016) "Eksplorasi geomagnetik untuk penentuan keberadaan pipa air di bawah permukaan bumi," Jurnal Geosaintek, hal. 157-164. 
